\title{
NETWORK MODEL OF UNDERWATER COMPLEX PROJECT FOR CLOSED WATER AREA MONITORING
}

\section{МЕРЕЖЕВА МОДЕЛЬ ПРОЕКТУ СТВОРЕННЯ ПІДВОДНОГО КОМПЛЕКСУ ДЛЯ МОНІТОРИНГУ МІЛКОВОДНИХ АКВАТОРІЙ}

\author{
Heorhii V. Babkin ${ }^{1}$ \\ georgii.babkin@nuos.edu.ua \\ ORCID: 0000-0001-6303-0993 \\ Pavlo V. Maidaniuk ${ }^{2}$ \\ udm@dsszzi.gov.ua \\ ORCID: 0000-0002-1289-019X
}

Г. В. Бабкін ${ }^{\mathbf{1}}$

канд. техн. наук

П. В. Майданюк², ст. інспектор

${ }^{1}$ Admiral Makarov National University of Shipbuilding, Mykolaiv ${ }^{2}$ State Service of Special Communication and Information Protection of Ukraine in Mykolaiv region, Mykolaiv

${ }^{1}$ Національний університет кораблебудування імені адмірала Макарова, м. Миколаїв

${ }^{2}$ Управління Державної служби спеціального зв'язку та захисту інформації України в Миколаївській області, м. Миколаїв

\begin{abstract}
Currently, the search, inspection and monitoring of coastal zones and port water areas is impossible without the use of modern technical means of marine robotics. According to the results of research in the field of creating marine robotics for various purposes, we can conclude that underwater systems are the most effective for performing inspection work. This makes it relevant to bring the results of the scientific school of Ukrainian robotics to the domestic and foreign markets of services for the development and creation of competitive tools for marine robotics. In recent years, Ukraine has formed a large amount of work to protect the waters of ports and naval bases. Strengthening the relevance of this thesis is the growing need for technical means to ensure the functions of protecting the state border of the state, performing environmental monitoring, providing the population with products of marine origin, etc. At the same time, there are dozens of devices, and this is a series of marine robotics what all boats, ships and port security services should be equipped with. In world practice, marine robotic complexes of various types are used for underwater operations related to monitoring the state of their bottom surface. But the organizational, technical and scientific foundations for the application of this technique and technologies for its application are not disclosed, obviously, for reasons of maintaining trade secrets and ensuring competitiveness.

Purpose. Development of a network model for a project to create a marine complex for monitoring the state of the bottom surface of port water areas and marine bases as the basis for mathematical modeling of the project management process for designing and serial production of marine robotics.

Method. When performing research, the following methods were used: methods and processes of project management standards and graph theory methods.

Results. A network model has been developed for a project to create a marine complex for monitoring the state of the bottom surface of port water areas and marine bases, which allows for the formation of an optimal schedule for design work by reducing the time for design work stages due to a clearer distribution of working time. The developed network model is the basis for a comprehensive mathematical model for the project of creating a marine complex for monitoring the state of the bottom surface of port water areas and sea bases. A hierarchical structuring of the project's work has been carried out, which allows to determine the total amount of human resources and time spent on the project of creating a marine robotics tool with a towed signal buoy. A key factor affecting the duration and cost of a project to create marine robotics of this type should be considered the provision of the required characteristics of a towed buoy and cable tug.
\end{abstract}

Scientific novelty. For the first time, a network model was built for the project of creating a marine complex for monitoring the state of the bottom surface of port water areas and sea bases.

Practical importance. Organization and planning of work on the creation of marine robotics.

Key words: marine robotics tool; network model; project management; project structure, life cycle.

Анотація. Виконання робіт з пошуку, інспекції та моніторингу прибережних зон і акваторій портів неможливо без застосування сучасних технічних засобів морської робототехніки. За результатами досліджень у галузі 
створення засобів морської робототехніки різного призначення можливо зробити висновок, що найбільш ефективними для виконання інспекційних робіт є підводні системи. Це робить актуальним виведення результатів наукової школи української робототехніки на внутрішній і зовнішній ринки послуг з розроблення і створення конкурентоздатних засобів морської робототехніки. В останні роки в Україні сформувався великий обсяг робіт iз захисту акваторій портів і морських баз. Підсиленням актуальності цієї тези є зростаюча необхідність у технічних засобах для забезпечення функцій з охорони державного кордону держави, виконання контролю за станом навколишнього середовища, забезпечення населення харчовими продуктами морського походження та ін. При цьому йде рахунок на десятки апаратів, а це вже серії засобів морської робототехніки, якими мають бути оснащені всі катери, кораблі та служби безпеки портів. У світовій практиці для підводних робіт, пов'язаних 3 контролем стану їхньої донної поверхні, використовуються морські комплекси різного типу. Але організаційно-технічні й наукові основи застосування цієї техніки й технологій ії застосувань не розкриваються, очевидно, 3 міркувань збереження комерційних таємниць і забезпечення конкурентоспроможності.

Мета. Розроблення мережевої моделі проекту створення морського комплексу для моніторингу стану донної поверхні акваторій портів і морських баз як основи математичного моделювання процесу управління проектом проектування та серійного виготовлення засобів морської робототехніки.

Методика. Під час виконання досліджень використовувались: методи та процеси стандартів управління проектами; методи теорії графів.

Результати. Розроблена мережева модель проекту створення морського комплексу для моніторингу стану донної поверхні акваторій портів і морських баз дозволяє сформувати оптимальний календарний план виконання конструкторських робіт шляхом скорочення термінів виконання етапів проектних робіт за рахунок більш чіткого розподілу робочого часу. Розроблена мережева модель $є$ основою для комплексної математичної моделі проекту створення морського комплексу для моніторингу стану донної поверхні акваторій портів і морських баз. Виконана ієрархічна структуризація робіт проекту дозволяє визначити загальний обсяг людських ресурсів та витрат часу на виконання проекту створення ЗМР із буксируваним сигнальним буєм. Ключовим фактором, який впливає на тривалість і вартість проекту створення засобів морської робототехніки такого типу, слід вважати забезпечення необхідних характеристик буксируваного буя та кабель-буксира.

Наукова новизна. Вперше побудовано мережеву модель проекту створення морського комплексу для моніторингу стану донної поверхні акваторій портів і морських баз.

Практична значимість. Організація та планування робіт зі створення засобів морської робототехніки.

Ключові слова: засіб морської робототехніки; мережева модель; управління проектом; структура проекту, життевий цикл.

\section{ПОСТАНОВКА ЗАДАЧІ}

На даній час виконання робіт з моніторингу мілководних акваторій (інспекції прибережних зон та акваторій портів, пошуку затонулих об'єктів, цифрового картографування донної поверхні тощо) неможливо без застосування сучасних технічних засобів морської робототехніки (далі - ЗМР). За результатами досліджень у галузі створення ЗМР різного призначення можливо зробити висновок, що найбільш ефективними для виконання інспекційних робіт є підводні апарати і системи. Це робить актуальним виведення результатів наукової школи української робототехніки на внутрішній і зовнішній ринки послуг з розроблення і створення конкурентоздатних 3МР.

Підсиленням актуальності цієї тези є зростаюча необхідність у технічних засобах для забезпечення функцій з охорони державного кордону держави, виконання контролю за станом навколишнього середовища, забезпечення населення харчовими продуктами морського походження та ін. При цьому йде рахунок на десятки апаратів, а це вже серії ЗМР, якими мають бути оснащені всі катери, кораблі та служби безпеки портів $[1 ; 2]$.

\section{АНАЛІЗ ОСТАННІХ ДОСЛІДЖЕНЬ І ПУБЛІКАЦІЙ}

В останні роки в Україні сформувався великий обсяг робіт із захисту акваторій портів і морських баз. У світовій практиці для підводних робіт, пов'язаних 3 контролем стану їхньої донної поверхні баз, використовується морські комплекси різного типу [3-5].

Так, у [3] розглядаються переваги застосування одного з видів ЗМР - автономних ненаселених підводних апаратів для екологічного моніторингу підводного простору, проте питання його створення (проектування та побудови) не розглядаються.

У [4] досліджується усталений рух моделі двохступеневої буксируваної системи та кабель-буксиру, однак питання управління процесами ії проектування залишились поза увагою авторів.

Основи системного підходу застосовано у роботі [5] під час гідродинамічного аналізу кабель-буксирів (далі - КБ) ЗМР. Автори на деяких комерційно наявних КБ вивчали їхні експлуатаційні характеристики, однак необхідні системні узагальнення щодо управління процесами створення таких елементів ЗМР у цілому не зроблені. 


\section{ЕКОНОМІКА ТА МЕНЕДЖМЕНТ №2-2019}

У роботі [6] розглядається проектування і створення прив'язного телекерованого підводного апарата для малих глибин (до 20 метрів). Детально аналізуються питання зниження ціни виробу, проте інші показники проектування (терміни виконуваних робіт, загальна організація робіт) авторами не розглядається.

Таким чином, у наведених та інших зарубіжних публікаціях організаційно-технічні й наукові основи застосування цієї техніки й технологій ії застосування не розкриваються, очевидно, з міркувань збереження комерційних таємниць i забезпечення конкурентоспроможності.

Аналіз показує, що на цей час в Україні практичний досвід проектування і застосування підводних апаратів для виконання підводно-технічних робіт $\epsilon$ тільки у двох організацій - Національного університету кораблебудування імені адмірала Макарова і Державної служби з надзвичайних ситуацій України [7]. Досвід виконання таких робіт свідчить, що на цей час відсутні теорія, методи й методики, які дозволили б сформувати технічне завдання на розроблення й побудову відповідної підводної техніки для виконання такого роду робіт.

\section{ВІДОКРЕМЛЕННЯ НЕ ВИРІШЕНИХ РАНІШЕ ЧАСТИН ЗАГАЛЬНОЇ ПРОБЛЕМИ}

Враховуючи масштабність і загальнодержавний характер задачі, для іiї успішного розв'язку необхідно формування міжвідомчої спеціалізованої організації для виробництва підводної робототехніки, розгортання iї масового створення і застосування на всіх потенційно небезпечних акваторіях держави.

Враховуючі специфіку виконуваних завдань та призначення засобів морської робототехніки з буксируваним радіобуєм, інформація про їхні характеристики та технології їх створення і застосування $\epsilon$ обмеженою.

\section{МЕТА ДОСЛІДЖЕННЯ}

Розроблення мережевої моделі проекту створення морського комплексу для моніторингу стану донної поверхні акваторій портів і морських баз як основи математичного моделювання процесу управління проектом проектування та серійного виготовлення засобів морської робототехніки.

\section{МЕТОДИ, ОБ'СКТ ТА ПРЕДМЕТ ДОСЛІДЖЕННЯ}

Об’єктом дослідження є процеси управління проектами створення засобів морської робототехніки. Предметом дослідження є моделі, методи та механізми управління проектами створення засобів морської робототехніки. Науково-прикладна задача управління проектами створення засобів морської робототехніки вирішувалась у межах новітніх концепцій та сучасних методологій управління проектами. Під час виконання досліджень використовувались методи та про- цеси стандартів управління проектами і методи теорії графів.

\section{ОСНОВНИЙ МАТЕРІАЛ}

Сьогодні на фоні зростання рівня терористичної загрози питанню охорони закритих акваторій приділяється багато уваги. Найбільш поширеними способами є застосування водолазних технологій та технологій 3 використанням сучасних засобів морської робототехніки. Використання таких методів пов'язано 3 низкою недоліків [8-10]. По-перше, застосування водолазних технологій передбачає присутність людини у водному середовищі, безпосередньо біля джерела потенційної загрози. Крім того, приймаючи до уваги розміри акваторій, обмеженість знаходження водолазного фахівця під водою та низьку швидкість його руху, можливо зробити висновок, що роботи з моніторингу стану донної поверхні будуть тривати досить довго.

По-друге, застосування сучасних ЗМР для виконання робіт з моніторингу також мають певний перелік недоліків, а саме: прив'язні ЗМР потребують використання спеціалізованих носіїв, які повинні під час виконання робіт постійно змінювати місце якірної стоянки в акваторії, в якій здійснюється активний рух плавзасобів; застосування автономних ЗМР потребує чіткого планування місії, детального програмування траєкторії його руху й отримання результатів обстеження тільки після завершення програмного циклу; застосування ЗМР із дистанційним керуванням потребує використання складного обладнання для звукопідводного зв'язку та через обмеженість смуги пропуску каналів зв'язку, дискретність одержуваної інформації. Крім того, застосування автономних ЗМР не дає можливості виконувати топологічну прив'язку знайдених об'єктів та потенційних загроз із застосуванням технології GPS, оскільки радіосигнал під водою не розповсюджується.

Вирішення цієї проблеми можливо в разі застосування 3МР автономного типу з буксируваним сигнальним буєм, схему якого наведено на рис. 1.

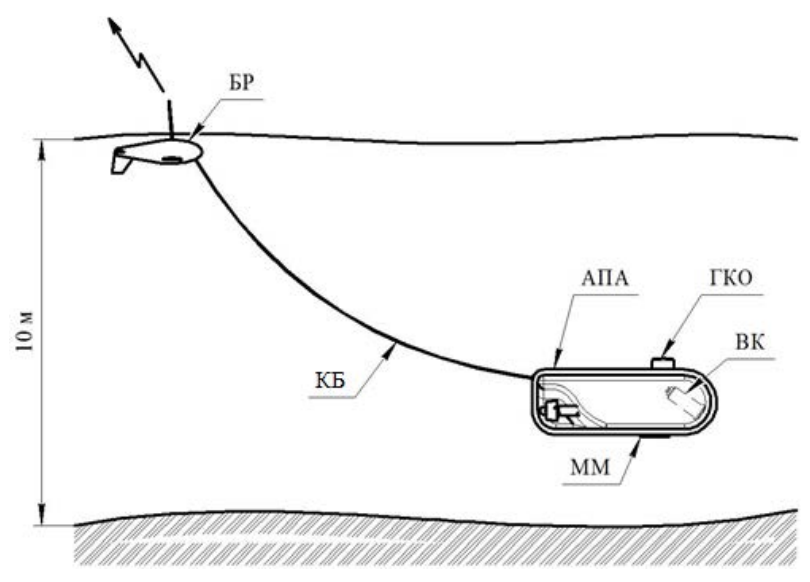

Рис. 1. Автономний ЗМР із буксируваним сигнальним буєм 
До складу такого ЗМР входять безпосередньо автономний підводний апарат (АПА), оснащений для пошуку і моніторингу магнітометром (MМ), гідролокатором кругового огляду (ГКО) та відеокамерою (ВК), кабель-буксир (КБ) та буксируваний радіобуй (БР).

Такий підводний комплекс позбавлений недоліків, які перераховані раніше. Завдяки більш широкій смузі пропуску радіоканал дозволяє отримувати інформацію від ЗМР та керувати їм у реальному часі, розміщення на БР антени та обладнання приймача забезпечить оперативну прив'язку апарату до координат системи GPS. Для забезпечення робіт такий ЗМР не потребує наявності спеціалізованого носія, керування може виконуватися 3 будь-якого місця причальних споруд або портового приміщення. Крім того, тривалість місії обмежена лише ємністю акумуляторної батареї АПА.

Кожна 3 основних систем такого комплексу $є$ закінченим технічним виробом і в межах одного класу технічних засобів - універсальним, тобто може бути використана в складі будь-якого ЗМР даного класу або серії. Крім цього, використання у всіх елементах комплексу однотипних вузлів і механізмів, відповідно до модульного принципу побудови $[11 ; 12]$, дозволяє значно підвищити живучість і ремонтопридатність вузлів, а також значно скоротити час і трудовитрати на проектні, будівельні та ремонтно-відновлювальні роботи в разі виникнення аварійних ситуацій в процесі експлуатації комплексу.

Ефективно реалізувати проект такого ЗМР можна тільки за детальної побудови й аналізу всього життєвого циклу, побудувавши мережеву модель проекту створення комплексу.

Визначивши відповідно до структурної моделі проекту повний перелік усіх робіт, можна здійснювати побудову мережевої моделі. Відображаючи всі види робіт, мережева модель ураховує можливі стани переліку робіт, терміни їх виконання, можливі порушення цих термінів і наслідки порушень.

Мережева модель проекту створення ЗМР для моніторингу закритих акваторій на етапі виконання проектних робіт наводиться на рис. 2 .

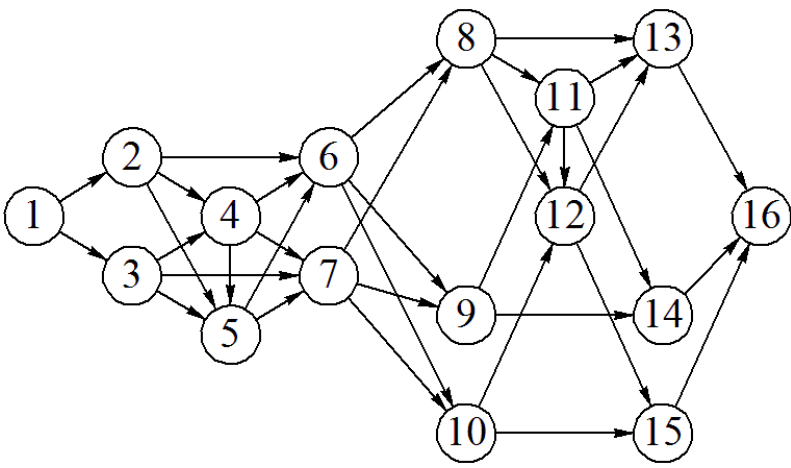

Рис. 2. Мережева модель проекту створення ЗМР
На відміну від запропонованої у [13; 14] мережевої моделі, до складу моделі, яка зображена на рис. 2, входить п'ять комплексів конструкторських робіт, а саме роботи по конструюванню: буксируваного радіобуя (2); буксирної лебідки (3); інженерних систем (9); поста керування та забезпечення (10); підводного апарата-буксирувальника (8).

Відповідно до рис. 2 роботи по конструюванню буя та буксирної лебідки повинні виконуватись одночасно, оскільки їхнє електронне обладнання (3) та механізми (4) тісно пов'язані. Остаточна конструкція корпусу гідродинамічного обтічника (6) здійснює вплив на кінцеві масогабаритні показники лебідки (7). Лише після завершення конструкторських робіт зі створення буя та кабельної лебідки можуть виконуватись роботи по конструюванню апарата-буксирувальника, його механізмів (11); електронного обладнання (12), корпусу апарата (13) та зі створення поста керування й інженерних систем.

Застосовуючи для створення ЗМР такого типу модульного принципу побудови, якій запропоновано у $[14 ; 15]$ та апробовано під час виконання низки проектних робіт, що проводились у НДІ підводної техніки НУК ім. адм. Макарова протягом останніх 10 років, можливо максимально оптимізувати етапи виконання конструкторських робіт.

Однак слід звернути увагу та те питання, що одночасне виконання конструкторських робіт по усіх елементах комплексу ЗМР неможливо. Пов'язано це 3 тим, що на основні характеристики підводного апарата (буксирувану потужність; швидкість руху; час автономної роботи; масогабаритні показники) значно впливають характеристики обладнання буя. Тому роботи, що пов'язані зі створенням буя та буксирної лебідки, об'єднані єдиним терміном робіт. Таким чином, конструкторські роботи зі створення ЗМР можуть бути розділені на два етапи - етап створення комплексу «буксируваний буй - кабель-буксир - буксирна лебідка»; етап створення підводного апаратабуксирувальника.

Математичний опис ЗМР із буксируваним сигнальним буєм може бути представлений як система функцій, яка описує повний перелік систем, елементів та матеріалів, що надходять до його складу:

$$
\left\{\begin{array}{l}
M_{b}=f\left(O_{b}, R_{b}, K_{b}, U_{b}, D_{b}\right), \\
M_{k}=f\left(O_{k}, R_{k}\right), \\
M_{n}=f\left(O_{n}, R_{n}, K_{n}, U_{n}, D_{n}\right),
\end{array}\right.
$$

де $M_{b}, M_{k}, M_{n}$ - математичні моделі, відповідно, буксируваного буя, кабель-буксиру та підводного апарата-буксирувальника; $O_{b}, O_{k}, O_{n}$ - опис об'єкту конструювання, відповідно, буксируваного буя, кабель-буксиру та підводного апарата-буксирувальника; $R_{b}, R_{k}, R_{n}$ - роботи по конструюванню, відповідно, буксируваного буя, кабель-буксиру та підводного 
апарата-буксирувальника; $K_{b}, K_{k}, K_{n}$ - комплектуючі об'єкту конструювання, відповідно, буксируваного буя, кабель-буксиру та підводного апарата-буксирувальника; $U_{b}, U_{k}, U_{n}$ - збиральні одиниці об'єкту конструювання, відповідно, буксируваного буя, кабельбуксиру та підводного апарата-буксирувальника; $D_{b}$, $D_{k}, D_{n}$ - деталі об'єкту конструювання, відповідно, буксируваного буя, кабель-буксиру та підводного апарата-буксирувальника.

Таким чином, математичний опис структури проекту буде мати вигляд:

$$
M_{z m r}=f\left(M_{o b}, M_{k b}, U, R P, E, W, D\right)
$$

де $M_{z m r}$ - математична модель структури проекту ЗМР; $M_{o b}$ - математичне моделювання гідродинаміки буксируваного радіобуя; $M_{k b}$ - математичне моделювання гідродинаміки кабель-буксиру; $U$ - функціональні блоки проекту; $R P$ - розділи проекту, у відповідності до робіт за фахом; $E$ - роботи підрядників та субпідрядників; $W$ - комплекти конструкторської документації; $D$ - робочі креслення.

На підставі запропонованої мережевої моделі може формуватися оптимальний план робіт проекту зі створення автономного ЗМР із буксируваним сигнальним буєм. Для цього потрібно визначити складники такого засобу та загальну структуру робіт з його створення. До складу типового ЗМР (рис. 3) входять такі елементи:

- підводний апарат (ПА);

- буксируваний радіобуй (БР);
- система керування (СК);

- навісне обладнання (НО);

- інженерні системи (IC).

Застосовуючи для аналізу структури проекту змішану декомпозицію (рис. 4), отримуємо повну структуру робіт проекту з урахуванням як освоєних, так і нових процесів створення наукоємної підводної продукції.

При цьому вираз, що відображає загальний обсяг робіт зі створення ЗМР із буксируваним сигнальним буєм, буде мати такий вигляд:

$$
W_{3 \mathrm{MP}}=\sum_{i} \varepsilon_{i} W_{3 \mathrm{MP} i}=\sum_{i} \varepsilon_{i} \sum_{j} W_{3 \mathrm{MP} i j}
$$

де $\varepsilon_{\mathrm{i}}-$ вагові коефіцієнти, що визначають внесок $i$-ї складової частини проекту;

$\sum W_{\text {змРі }}-$ обсяг робіт проекту створення ЗМР,

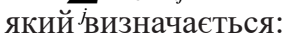

$W_{\text {змР1 }}=\sum W_{3 П j}-$ обсяг робіт, що пов'язаний без-

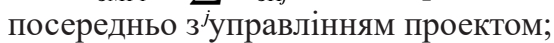

$W_{\text {змР2 }}=\sum W_{\text {ПА }}-$ обсяг робіт, пов'язаний зі створенням підводного апарату;

$W_{\text {змР3 }}=\sum W_{\text {БР }}-$ обсяг робіт, пов'язаний зі створенням буксинруваного радіобуя;

$W_{\text {змР4 }}=\sum W_{\mathrm{CK} j}-$ обсяг робіт, пов'язаний зі створенням системи керування;

$W_{\text {змР5 }}=\sum W_{\text {но }}-$ обсяг робіт, пов'язаний зі створенням навісніого обладнання;

$W_{\text {змР6 }}=\sum W_{\text {ICj }}-$ обсяг робіт, пов'язаний зі створенням інженіерних систем.

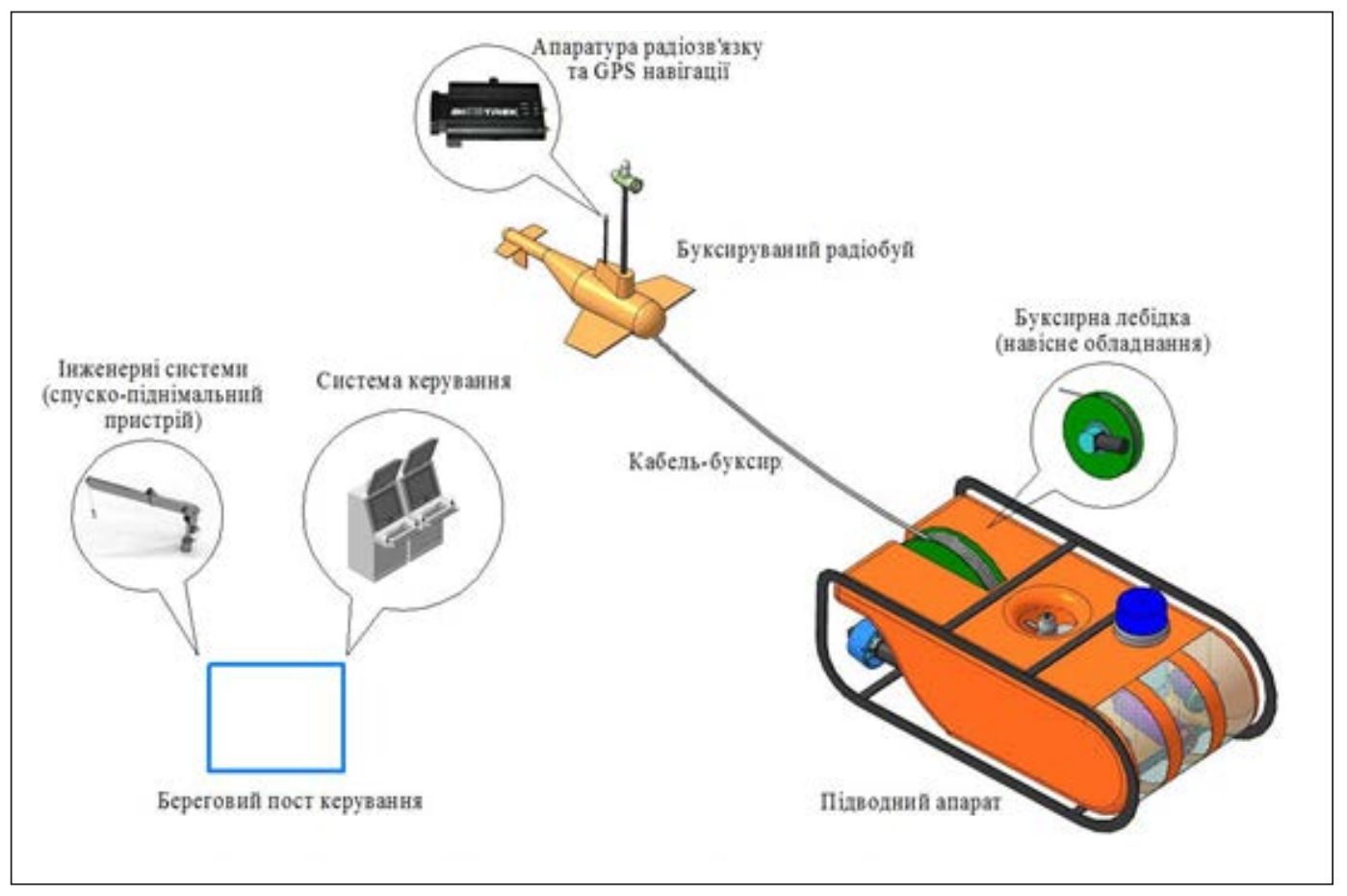

Рис. 3. Складники ЗМР із буксируваним сигнальним буєм 


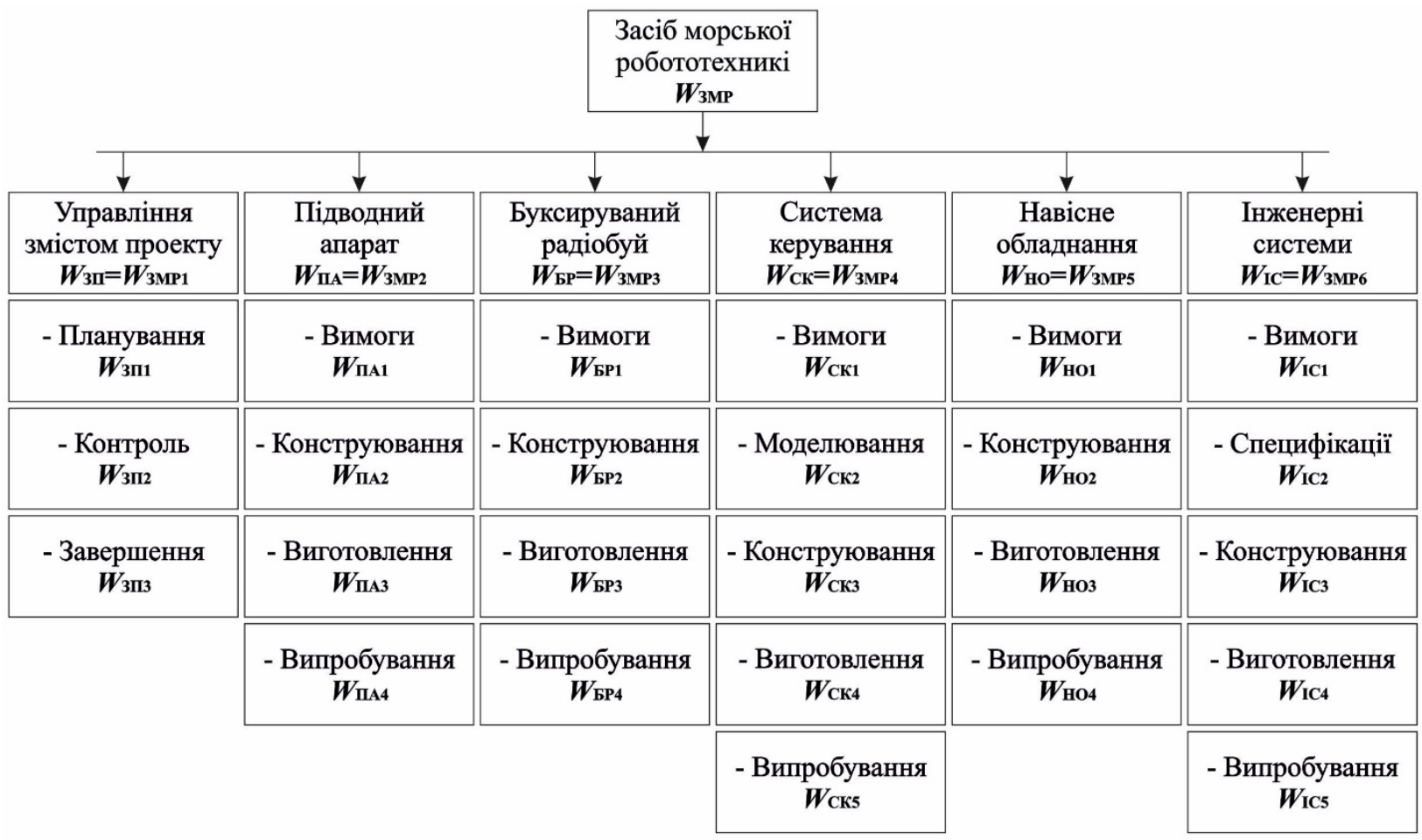

Рис. 4. Структура робіт проекту створення ЗМР із буксируваним сигнальним буєм

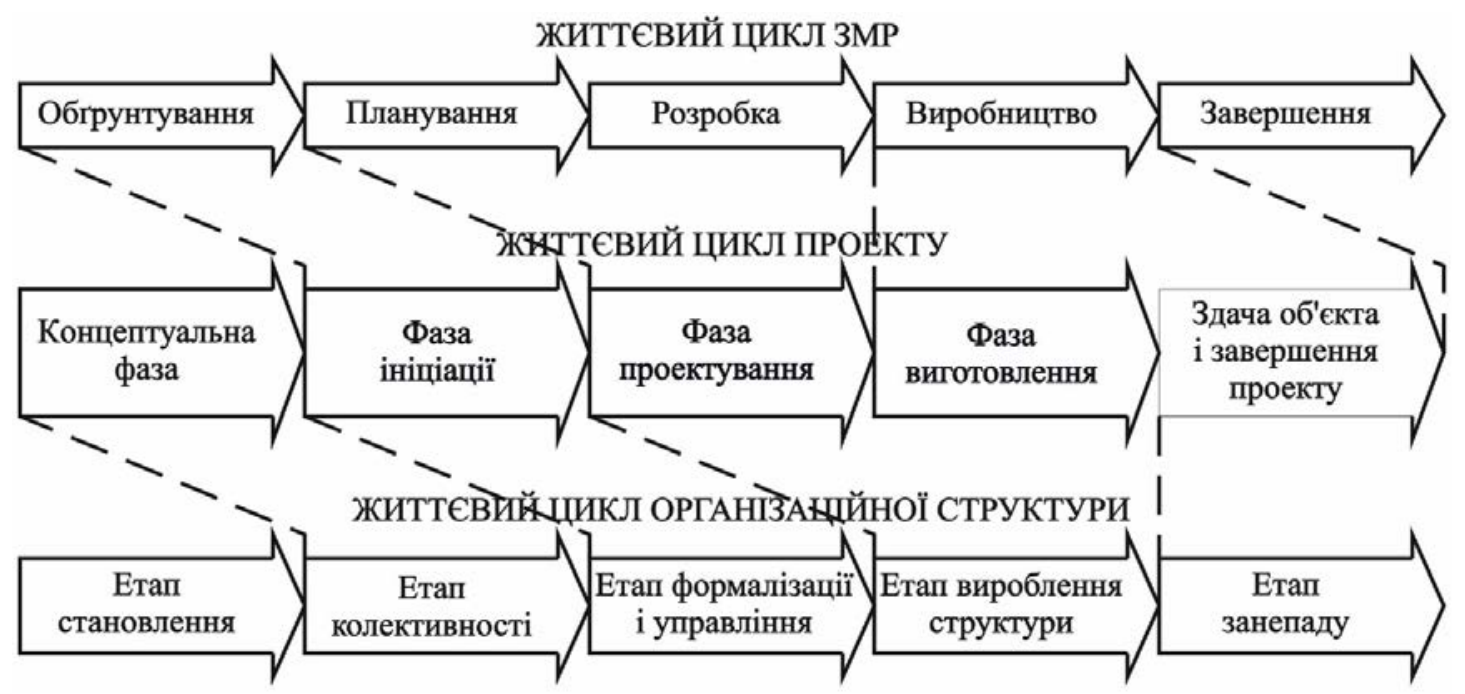

Рис. 5. Етапи життєвих циклів

Якщо взяти до уваги, що життєві цикли (рис. 5) 3МР, проекту 3 його створення та організаційної структури, яка виконує роботи зі створення ЗМР, можливо виконати розподіл робіт, пов'язаних з його створенням по етапах життєвих циклів, якій буде мати вигляд, наведений у табл. 1 [13].

Узагальненим результатом планування буде отримано зміст проекту створення ЗМР із буксируваним сигнальним буєм, якій включає у себе:
- комплект документів (обгрунтування проекту, опис характеристик серії приладів і апаратів 3МР та їхніх технічних і виробничих характеристик як продукту проекту тощо);

- опис та обгрунтування прийнятої структури проекту;

- опис та обгрунтування плану управління змістом проекту з описом об' єктів і точок контролю, критеріїв оцінки поточних та остаточних результатів проекту. 
ЕКОНОМІКА ТА МЕНЕДЖМЕНТ №2 2019

Таблиця 1. Розподіл робіт, пов’язаних зі створенням 3МР, по етапах життєвих циклів

\begin{tabular}{|c|c|c|c|c|c|c|c|c|c|}
\hline Етапи & ЖЦВ & & & $T_{\text {мд }}$ & $\bar{T}_{\text {НДР }}$ & $T_{\text {ДКР }}+T_{\text {ТПв }}$ & \multicolumn{2}{|c|}{$T_{\mathrm{CB}}+T_{\mathrm{EK}}$} & $T_{\mathrm{yT}}$ \\
\hline Da & ЖЦП & & $T_{\mathrm{K \Phi}}$ & $T_{\text {КП }}$ & \multicolumn{2}{|c|}{$T_{\text {ФП }}$} & $T_{\Phi \mathrm{B}}$ & $T_{3 \Pi}$ & \\
\hline циклу проекту & ЖЦОС & $T_{\mathrm{CT}}$ & $T_{\text {Кл }}$ & $T_{\Phi \mathrm{y}}$ & \multicolumn{3}{|c|}{$T_{\mathrm{BC}}$} & \multicolumn{2}{|c|}{$T_{\text {зп }}$} \\
\hline $\begin{array}{c}\text { Управління змістом } \\
\text { проекту }\end{array}$ & & $W_{\text {зпі }}$ & \multicolumn{5}{|c|}{$W_{\text {зП2 }}$} & \multicolumn{2}{|c|}{$W_{\text {зпз }}$} \\
\hline $\begin{array}{c}\text { Створення підводного } \\
\text { апарата }\end{array}$ & & & & $W_{\text {ПА } 1}$ & & $W_{\text {ПА } 2}$ & $W_{\text {ПА } 3}$ & $W_{\text {ПА } 4}$ & \\
\hline $\begin{array}{c}\text { Створення } \\
\text { буксируваного радіобуя } \\
\end{array}$ & & & \multicolumn{2}{|c|}{$W_{\text {БР1 }}$} & $W_{\text {БР2 }}$ & $W_{\text {БР3 }}$ & $W_{\text {БР } 4}$ & & \\
\hline $\begin{array}{c}\text { Створення системи } \\
\text { керування }\end{array}$ & & & & $W_{\mathrm{CK} 1}$ & $W_{\mathrm{CK} 2}$ & $W_{\mathrm{CK} 3}$ & $W_{\mathrm{CK} 4}$ & $W_{\mathrm{CK} 5}$ & \\
\hline $\begin{array}{c}\text { Створення навісного } \\
\text { обладнання }\end{array}$ & & & & $W_{\mathrm{HO} 1}$ & & $W_{\mathrm{HO} 2}$ & $W_{\mathrm{HO} 3}$ & $W_{\mathrm{HO} 4}$ & \\
\hline $\begin{array}{c}\text { Створення інженерних } \\
\text { систем }\end{array}$ & & & & $W_{\mathrm{IC} 1}$ & $W_{\mathrm{IC} 2}$ & $W_{\text {IC3 }}$ & $W_{\mathrm{IC} 4}$ & $W_{\text {IC5 }}$ & \\
\hline
\end{tabular}

\section{ОБГОВОРЕННЯ ОТРИМАНИХ РЕЗУЛЬТАТІВ}

Отримані результати дозволяють виконувати ефективний розподіл робіт проекту створення засобів морської робототехніки з буксируваним радіобуєм по етапах життєвих циклів. Зроблені висновки були отримані в НДІ підводної техніки НУК ім. адм. Макарова під час робіт зі створення сучасних зразків підводної техніки.

\section{ВИСНОВКИ}

Розроблена мережева модель проекту створення морського комплексу для моніторингу стану донної поверхні акваторій портів і морських баз дозволяє сформувати оптимальний календарний план виконання конструкторських робіт шляхом скорочення термінів виконання етапів проектних робіт за рахунок більш чіткого розподілу робочого часу.

Розроблена мережева модель $\epsilon$ основою для комплексної математичної моделі проекту створення морського комплексу для моніторингу стану донної поверхні акваторій портів і морських баз.

Виконана ієрархічна структуризація робіт проекту дозволяе визначити загальний обсяг людських ресурсів та витрат часу на виконання проекту створення 3МР із буксируваним сигнальним буєм. Ключовим фактором, який впливає на тривалість і вартість проекту створення засобів морської робототехніки такого типу, слід вважати забезпечення необхідних характеристик буксируваного буя та кабель-буксира.

\section{REFERENCES}

[1] Pro «Polozhennia pro Derzhavnu inspektsiiu Ukrainy z bezpeky na morskomu ta richkovomu transporti»: Ukaz Prezydenta Ukrainy vid 8 kvitnia 2011 roku, № 447/2011.

[2] Pro zatverdzhennia «Polozhennia pro sluzhbu morskoi bezpeky portu (portovoho zasobu)»: Nakaz Ministerstva infrastruktury Ukrainy vid 25.08.2011 p. № 339.

[3] Tadahiro Hyakudome. (2011) Design of Autonomous Underwater Vehicle. International Journal of Advanced Robotic Systems. Vol. 8, No. 1 (2011), pp 122-130. URL: https://doi.org/10.5772/10536

[4] Linklater, Amy. (2005) Design and Simulation of a Towed Underwater Vehicle, Thesis submitted to the Faculty of the Virginia Polytechnic Institute and State University in partial fulfillment of the requirements for the degree of Master of Science In Aerospace Engineering. - Blacksburg, Virginia, 120 P. URL: https://vtechworks.lib.vt.edu/bitstream/handle/10919/33622/ AmyThesis.pdf? sequence $=1 \&$ isAllowed $=y$

[5] Nimmy, Thomas, Manoj, T. Issac. (2017) Analysis of Tow Cables. Universal Journal of Mechanical Engineering 5(5): 144-149.

[6] Yasser, M. Ahmed, Omar, Yaakob, Bong, K. Sun (2014) Design of a new low cost ROV vehicle. Jurnal Teknologi. № 69:7. 27-32.

[7] Ryzhkov, S. S., Blintsov, V. S., Yehorov, H. V., Zhukov, Yu. D., Kvasnytskyi, V. F., Koshkin, K. V., Krivtsun, I. V., Niekrasov, V. O., Cevriukov, V. V., Solonichenko Yu. V. (2011); za red. S.S. Ryzhkova. Stvorennia universalnykh transportnykh suden i zasobiv okeanotekhniky, Mykolaiv: Vydavnytstvo NUK. - 340 c.

[8] Blintsov, V. S. \& Kostenko, Yu. K. (2013). Avtomatizirovannaya sistema monitoringa gidrotekhnicheskikh sooruzheniy vodnykh transportnykh putey [Automated monitoring system for hydraulic structures of waterways] Portovi tekhnologiï ta tekhnika moreplavannya: materiali Vseukraïnskoï naukovo-tekhnichnoï konferentsiï z mizhnarodnoyu uchastyu. Mikolaiv, NUK, 152-155 
[9] Sidenko, K. S. \& Golobokov, S. A. (2008). Zashchita portov i odinochnykh sudov s pomoshchyu neobitayemykh podvodnykh apparatov [Protection of ports and single vessels with unmanned underwater vehicles]. Morskoy Flot, 5, 28. Retrieved from http://www.morflot.su/archives/articles1811file.pdf.

[10] Shcherbakov, G. N., Shlykov, Yu. A. \& Brovin, A. V. (2008). Zashchita vazhnykh obyektov ot podvodnogo terrorizma [Protecting important objects from underwater terrorism]. Spetsialnaya Tekhnika, 2. Retrieved from http://www.bnti.ru/ aprintit.asp?aid=966.

[11] Volodymyr, Blintsov, Pavlo, Maidaniuk, Andrii Sirivchuk. (2019) Improvement of Technical Supply of Projects of Robotized Monitoring of Underwater Conditions in Shallow Water Areas. «EUREKA: Physics and Engineering», Number 3. Pages 41-49. DOI: 10.21303 / 2461-4262.2019.00893.

[12] Blintsov, O. V. \& Hrytsayenko, M. H. (2014). Telekerovani pidvodni aparaty na sluzhbi morehospodars'koyi diyal'nosti Mykolayivshchyny [Remotely operated vehicle on the service of the maritime business of Nikolaev]. Shipbuilding \& marine infrastructure, 1, 28-33.

[13] Babkin, H.V. (2007) Setevaia model upravlenyia proektom sozdanyia morskykh kompleksov dlia obezvrezhyvanyia podvodnыkh potentsyalno opasnыkh obъektov, Vostochno-evropeiskyi zhurnal peredovykh tekhnolohyi. Kharkov, 3/6(27). - C. 7-9.

[14] Babkin, H. V., Blintsov, V. S., Druzhynin, Ye. A., Kiiko, S. H., Knyrik, N. R., Koshkin, K. V., Krytskyi, D. M., Ryzhkov, S. S., Slobodian S. O., (2017) Upravlinnia uspishnymy proektamy stvorennia skladnoi tekhniky. Mykolaiv : Vydavnytstvo Torubary V. V., $336 \mathrm{c}$.

[15] Blintsov V. S., Sirivchuk A. S. (2018) Zastosuvannia avtonomnykh pidvodnykh aparativ z radiobuiem dlia monitorynhu pidvodnoi obstanovky v portovykh raionakh, Zbirnyk naukovykh prats NUK, 3-4(474), 54-59.

\section{СПИСОК ВИКОРИСТАНОЇ ЛІТЕРАТУРИ}

[1] Про «Положення про Державну інспекцію України з безпеки на морському та річковому транспорті» : Указ Президента України від 8 квітня 2011 року, № 447/2011.

[2] Про затвердження «Положення про службу морської безпеки порту (портового засобу)» : Наказ Міністерства інфраструктури України від 25.08.2011 р. № 339.

[3] Tadahiro, Hyakudome. (2011) Design of Autonomous Underwater Vehicle. International Journal of Advanced Robotic Systems. Vol. 8 №. 1. P. 122-130. URL: https://doi.org/10.5772/10536

[4] Linklater, Amy. (2005) Design and Simulation of a Towed Underwater Vehicle. Thesis submitted to the Faculty of the Virginia Polytechnic Institute and State University in partial fulfillment of the requirements for the degree of Master of Science In Aerospace Engineering. Blacksburg, Virginia. 120 P. URL: https:/vtechworks.lib.vt.edu/bitstream/handle/10919/33622/ AmyThesis.pdf? sequence $=1 \&$ isAllowed $=y$

[5] Nimmy, Thomas, Manoj, T. Issac. (2017) Analysis of Tow Cables. Universal Journal of Mechanical Engineering. 5 (5): 144-149.

[6] (2014) Design of a new low cost ROV vehicle / M., Yasser. Jurnal Teknologi. № 69:7. P. 27-32.

[7] (2011) Створення універсальних транспортних суден і засобів океанотехніки / С. С., Рижков ; за ред. С. С., Рижкова. Миколаїв : Видавництво НУК, 340 с.

[8] Блинцов, В. С., Костенко, Ю. К. (2013) Автоматизированная система мониторинга гидротехнических сооружений водных транспортных. Портові технології та техніка мореплавання: матеріали Всеукраїнської науково-технічної конференції з міжнародною участю. Миколаїв : НУК, 152-155.

[9] Сиденко, К. С., Голобоков, С. А. (2008) Защита портов и одиночных судов с помощью необитаемых подводных аппаратов. Морской Флот. № 5. С. 28. URL: http://www.morflot.su/archives/articles1811file.pdf/

[10] Щербаков, Г. Н., Шлыков, Ю. А., Бровин, А. В. (2008) Защита важных объектов от подводного терроризма. Сnециальная Техника. № 2. URL: http://www.bnti.ru/aprintit.asp?aid=966

[11] Volodymyr, Blintsov, Pavlo, Maidaniuk, Andrii Sirivchuk. (2019) Improvement of Technical Supply of Projects of Robotized Monitoring of Underwater Conditions in Shallow Water Areas. «EUREKA: Physics and Engineering». № 3. P. 41-49. DOI: $10.21303 / 2461-4262.2019 .00893$

[12] Блінцов, О. В., Гріцаєнко, М. Г. (2014) Телекеровані підводні апарати на службі морегосподарської діяльності Миколаївщини. Shipbuilding \& marine infrastructure. №. 1. С. 28-33.

[13] Бабкин, Г. В. (2007) Сетевая модель управления проектом создания морских комплексов для обезвреживания подводных потенциально опасных объектов, Восточно-европейский журнал передових технологий. Харьков. № 3/6 (27). C. 7-9.

[14] (2017) Управління успішними проектами створення складної техніки. / Г. В., Бабкін. Миколаїв : Видавництво Торубари В. В. 336 с.

[15] Блінцов, В. С., Сірівчук А. С. (2018) Застосування автономних підводних апаратів з радіобуєм для моніторингу підводної обстановки в портових районах. Збірник наукових пращь НУК. № 3-4 (474). С. 54-59. 